\title{
GUEST EDITORIAL \\ Reinvestigating the theory and practice gap in Participatory Educational Research
}

Participatory

Educational

Research

\section{Introduction}

Extensive school research worldwide illuminates different change processes and different innovative research models of teaching and learning practices, including teachers' professional development. Findings from educational research reveal a contradiction between educational theory and educational practice. Accordingly, the gap between theory and practice indicates a lack of credibility between researchers and practitioners. Qualitative research approaches frequently used are lesson study, learning study and action research, to mention a few. Educational inquiries investigate the continuous global change processes of classroom teaching, teachers and students learning, teachers' professional development and development of school organization and management at local and national level. Persistent issues in educational research are the gap existing between theory and practice and the lack of involvement of teachers as researchers (Biesta, 1994, 2007; Dewey and Bentley, 1945; Elliott, 1978; Nuthall, 2004; Stenhouse, 1975).

Educational policy makers demand evidence-based practice (Slavin, 2002) and scientific knowledge of "what works" in solving classroom problems and school problems in general. The demands yield educational research results that give technical solutions to practical teaching problems and learning problems. De Vries (1990) argues that on the one hand results of educational research can have a technical role and give solutions to problems and a cultural role aiming for improvement of practice. To bridge the gap between theory and practice, a direct link to classroom realities is needed, since "the teacher requires an explanatory theory of how different ways of managing the classroom and creating activities are related to student learning outcomes" (Nuthall, 2004, p. 274).

PER, and its cooperative and collaborative interaction forms, is not a new trend in educational research (Biesta, 2007; Cochran-Smith and Lytle, 1990; Hanfstingl et al, 2019; Korthagen, 2007; Pieters and Voogt, 2016; Pieters and De Vries, 2007). Previous scholars have investigated how theory and practice are intertwined (Schatzki et al, 2001) and how the machineries of knowledge construction (Knorr Cetina, 1999) develop social science research (Runesson, 2019). Moreover, scholars have suggested change of teachers' roles in classroom research so that teachers become researchers of their own teaching practice (Dewey, 1910/1974; Elliott, 1976, 1978; Stenhouse, 1975).

Notably, the intentions behind educational research as in PER are here taken to correspond to the intentions behind Participatory Action Research (PAR) (Chisholm and Elden, 1993; Elliott, 1978, 2007, 2012, 2015; Greenwood et al., 1993; Kemmis, 2009; Posch, 2019) with regard to research focus on participants' actions and change processes in context:

The intentional focus on collaborative research, action for social change and participant education shifts inquiry from an individual to a collective endeavor, intentionally aimed at transformative personal, organizational, and structural change. (Brydon-Miller and Maguire, 2009, p. 79)

Action research according to Elliott (1978) is an open concern with the everyday practical problems experienced by teachers unlike the "theoretical problems" defined by researchers

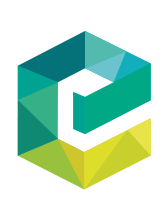

International Journal for Lesson and Learning Studies Vol. 9 No. 1,2020 C) Emerald Publishing Limited $2046-8253$ DOI 10.1108/IJLLS-01-2020-094 
IJLLS

9,1

within a discipline of knowledge. When teachers are engaged in solving a practical problem, they take part in a form of practical reasoning using their practical wisdom, phronesis, with collaborators (Oxenberg Rorty, 1980):

In this form of action research, teachers develop their understanding of what constitutes educational action by reflecting about their actions in the light of their aims and their aims in the light of their actions. (Elliott, 2007, p. 231)

Kemmis (2009, p. 470) asserts that action research aims to change practices, people's understandings of their practices and the condition they practice. Three forms of action research enhance this aim, technical action research (focused on improving control over outcomes); practical action research (focused on educating practitioners to act more wisely and prudently); and critical action research focused on emancipating people and groups from irrationality (Kemmis, 2009).

In the analyses of the PER studies and PAR studies, the focus is on actors, the degree of actors' participation in change processes, data collection, analysis of results and in making findings public. PER and PAR studies include change processes in teaching practices, i.e., of individuals and their understanding of their practices and the conditions under which they practice. To identify preconditions of PER and PAR studies, and to enhance the possibilities of knowledge creation, scholars have emphasized the importance of including in the studies: teachers' professional practice knowledge; teachers' conditions under which they teach in the classroom; and teachers' understandings of their practices.

The aim of this paper is to open a reinvestigation of the theory and practice gap and its consequences on teachers' participation in research of their own practice. Further, to explore if the gap is partly an artifact of the underlying epistemology made visible in the institutional practices of education and teacher training in PER. Accordingly, the overarching purpose is to gain deeper understanding of classroom teaching as PER. PER studies afford knowledge on how theory and practice are integrated and the complexity of problems of learning and teaching practice in classroom contexts.

An open call in the International Journal for Lesson and Learning Studies (IJLLS) invited researchers and practitioners to make contributions on the following themes related to PER:

- contribute to deepening our understanding of methodological and philosophical aspects of PER - more generally called developmental research;

- elucidate aims, purposes, knowledge claims and knowledge interests of different practice-based research approaches and abolish the gap between research and practice;

- articulate how different approaches can contribute to make teachers' conceptual and professional knowledge explicit, public and divisible beyond the local context; and

- make visible strategies for the assessment of ethical aspects and quality criteria in practice-based research.

Seven of those contributions are included in this special issue. These submissions represent educational research accomplished in Niger, Sweden, the UK and the USA. PER is here understood as an umbrella term for qualitative research approaches in social science, used to investigate sustainable and improved teaching practices, improved student learning outcomes and improved professional development of teachers' professional knowledge. Enacted transformations and changes, local and global, indicate sustainable and improved school systems, new curriculum reforms that concern the entire school organization and the entire school environment, not only teachers' teaching practices or students' learning outcomes.

In the studies submitted, different theoretical perspectives are applied in order to investigate the gap between theory and practice by involving teachers in research on teachers' practice. This paper is intended to open a discussion of the PER studies in the 
seven contributions, without addressing specific details of the research process in each of the seven contributions. First, the studies are investigated as developmental research with a focus on methodological and philosophical aspects for improved intentional teaching practice. Second, the focus is on how the studies bridge the gap between theory and practice in teaching and education. Third, the focus is on how to make teachers' knowledge visible and shareable (disseminated) beyond the local context. The paper draws some conclusions, implications and suggestions for future research.

\section{Developmental research as improved intentional educational practice}

Lesson study (Lewis, 2009) and learning study (Marton, 2015) are qualitative progressive research approaches which differently link individual's knowledge development with individual's personal development in the education context. In developmental research, theory and practice develops and is manifested as improved intentional practice in the research lesson (Van den Akker, 1999). Developmental educational research is symbolizing a kind of epistemic culture and an epistemic practice (Knorr Cetina, 1999; Schatzki et al., 2001). Research approaches are taken as intentional practices with certain aims and certain ways of making knowledge. Knorr Cetina (2001) claims that epistemic practices are organized unfolding objects of knowledge, such as the object of learning in learning study (Marton, 2015). Following that line of reasoning, learning study is metaphorically a "knowledge machinery" (Knorr Cetina's expression), including its object of learning with the critical aspects which unfolds and then bridging the theory and practice gap (Carlgren, 2020). Further, learning study can generate new knowledge applicable beyond the local setting (Carlgren, 2020; Kullberg et al., 2020). From a pragmatic philosophical perspective, the research process is a development of a means-ends relationship (Carlgren, 2020). In order to accomplish an end, some means must be developed. Means are means to some ends because their consequences are parts of the ends; "when we take ends without regards to means we degenerate into mere sentimentalism” (Dewey, 1957, p. 73).

Research, as a concept and as name, has usually a minimal definition according to Stenhouse (1981, pp. 103-104) as "systematic self-critical inquiry," with the addition "made public." However, Dewey and Bentley (1945, p. 226) argue, in discussing concepts and how we name concepts, for instance, "knowledge," that there are conditions/criteria that must be satisfied in order to regard the name relevant with determinable status. Such conditions are based on observations; tentative, postulational and hypothetical; and promote further observation. It is suggested that it is only "through prolonged factual inquiry [...] the word 'knowledge' [can] be given determinable status” (Dewey and Bentley, 1945, p. 226):

The above conditions amount to saying that the names we need have to do with knowings and knowns in and by means of continuous operations and test, in work in which any knowing or known establishes itself or fails to establish itself solely through continued search and research, and never on the grounds of any alleged outside "foundation", "premise", "axiom" or ipse dixit assertion." (Dewey and Bentley, 1945, pp. 226-227)

"What makes lesson study a form of high quality educational action research?" (Elliott, 2020, p. 3). In order to assess lesson study as a form of high-quality practice-based action research, Elliott (2020) formulates a number of criteria, demands or conditions. As an action research project, it must take a practical problem experienced by teachers as a focus and a point of departure. During the solving process of the problem, teachers' professional knowledge has to be visible, shared and tested in the project group among colleagues in a democratic conversational process of practical reasoning (phronesis) (Elliott, 2007, p. 231):

Within this deliberative and self-reflexive process of practical reasoning means [teaching strategies] ends [aims] become objects of mutual reflection. Teachers not only call into question

Participatory Educational Research 
IJLLS
9,1

their teaching strategies (means) but also their aims (ends) to which their strategies are directed. They modify each by reflecting on the other. (Elliott, 2020, p. 5)

Further, educational action research must also rely on certain virtues such as integrity, honesty, curiosity and open-mindedness among teacher in collaborative work (Elliott, 2020).

Carlgren (2020) focuses on the methodology of learning study as paedeutic research; referring to research as for teachers and not on teachers and as research into problems and challenges faced by teachers in their professional practice:

It may appear that learning study, with its strong focus on specific objects of learning, is extremely instrumental and difficult to reconcile with the concept of Bildung. (Carlgren, 2020, p. 10)

The process of Bildung alludes to a perspective on content and processes of education through teaching as a core of the teachers' profession. As mentioned, the object of learning is not a static concept for teachers and learners in the teaching process:

Depending on the knowing of the knowers it [object of learning] appears in certain ways that may be extended and become part of their individual Bildung processes. The focus on knowings connects the world of knowledge to the knower's personal development. (Carlgren, 2020, p. 10)

Ousseini (2020) takes the lesson study approach as the learning object for a group of four preservice English First Language (EFL) teachers in an initial EFL teacher education program. Participants receive instruction to read two publications on lesson study and to reflect collaboratively on their separate readings as a group on a WhatsApp platform. Later, together they take part in a face-to-face discussion, where questions built on their previous session were introduced to them. Analysis of data indicates that participants have jointly reflected on factors that could affect application and the process of lesson study in the EFL classrooms. Findings, presented by the author, suggest that teacher educators use collaborative strategies in EFL training programs in order to make student teachers aware of methodological aspects and implications of the lesson study process as an alternative to the existing transmission models of teaching.

Biza and Nardi (2020) investigate how 12 mathematics student teachers reflected on experienced critical classrooms incidents (Flanagan, 1954) after their first block of school placement. The student teachers produced 12 scripts for a group and a plenary discussion. The researchers analyzed the scripts of critical incidents from the perspective of social constructionism (Berger and Luckmann, 1966). Data were categorized according to a pre-formulated category system consisting of four characteristics: consistency, specificity, reification of pedagogical discourse and reification of mathematical discourse. The student teachers' scripts formed the base for the analysis of what they, as mathematics student teachers experienced in highly specific classrooms situations as critical incidents. Student teachers were actively discussing and reflecting on their experiences. The authors analyzed, categorized and summarized students' experiences of critical incidents in classrooms in the paper.

Whitney (2020) introduces a meta-study of lesson studies in the USA with the aim to examine what way and to what extent lesson study results are disseminated outside local context. Findings suggest that out of 45 journal articles about 27 percent of results of the lesson studies, as practiced in K-12 mathematics classrooms, were disseminated to other schools and other teachers.

In establishing a research environment for teacher-driven research, Andrée and Eriksson (2020) take a descriptive approach and use the framework of cultural-historical activity theory (Engeström, 1987, 2016) in order to outline the nature and reasons for teacher-driven research in the space between school and university. Even though, Lewis (2009, p. 95) argues that development of "a professional knowledge base for teaching may be an even 
more complicated endeavor than generally recognized, since it entails development of the knowers as well as the knowledge, and development of communities of practice, as well as individual teachers."

\section{The gap between theory and practice in teaching and education}

The terms theory and practice include two distinct concepts not intertwined but related to each other by underpinning epistemologies, and separated by a chasm. The discussion about the relationship between educational research and educational practice is an old one. It became evident "at least since the establishment of education as an academic field of study," for instance, in Germany in 1779, when the first Professor of Education was established (Biesta, 2007, p. 295).

Several of the contributions here start with the claim that there is a gap between research and practice and they try to bridge this gap (Andrée and Eriksson, 2020; Carlgren, 2020; Biza and Nardi, 2020; Ousseini, 2020). How to bridge the gap varies in the studies, for instance, as forms of "cooperation" or "collaborative interaction" between researchers and student teachers in teacher training programs or subject teachers (Kullberg and Runesson, 2013; Pang and Runesson, 2019). Kullberg et al. (2020) take the learning study approach to bridge the theory-practice gap by including teachers in collaborative work with researchers on improving students' learning and improving teaching as well as teachers' professional knowledge. The rationale is a phenomenographic non-dualistic ontology on which variation theory, a general learning theory and learning study have been based (Kullberg, 2010; Lo, 2012; Marton, 2015; Pang and Lo, 2012; Runesson, 2019).

In collaborative work among teachers and researchers, the aim of the learning study is to decide an object of learning that concerns a specific way of understanding something, for instance, a subject-specific concept. Variation is a prerequisite for discernment and learning is a function of discernment in variation theory. To make learning possible, certain patterns of variation manifested in the classroom make it possible for the students simultaneously to discern critical aspects of the object of learning (Lo, 2012; Marton, 2015). Critical aspects of the object of learning are what students have to discern in order improve their learning (Kullberg and Runesson, 2013; Mårtensson, 2019; Pang and Ki, 2016). These aspects are the "knowledge products" concerning instructional strategies of the learning study (Kullberg, 2010; Runesson et al., 2018). Differences in pattern of variation seem to have significant effect on student learning, when comparing three similarly arranged lessons in the same topic (Kullberg et al., 2020). Accordingly, Kullberg et al. (2020) suggest that there are specific features of the learning study that can link theory and practice, produce practice-based knowledge relevant beyond the local school context and bridge the theory-practice gap.

\section{Dissemination of knowledge beyond the local context}

In a learning study project, teachers are usually involved in all stages of the research process: in planning of lessons in the iterative form of the learning study, in the analysis of the pre-test and post-test of collected data, in the final stage of the experimental phase of the research process and in disseminating results (Kullberg, 2010; Kullberg and Runesson, 2013; Runesson, 2019; Runesson et al., 2018). In other research projects with other research approaches, for instance, in "research on teachers," when the final research results are summarized in an article submitted to a research journal, most often only researchers' names appear under the title.

Whitney (2020) examines the extent to which lesson study results are disseminated outside the local school context. To define the concept "sharing," Whitney (2020) uses how the final component "Sharing results" is defined in the "Collaborative Lesson Research" introduced by Takahashi and McDougal (2016). The component "sharing results" means that the lesson study cycle is not only for the research team and improvement of their
Participatory Educational Research 
IJLLS

9,1

practice, but also more broadly for the field of research. In coding the data, "Sharing" means dissemination of the learning of the lesson study team and in some cases other individuals' learning (those not belonging to the team) (Whitney, 2020, p. 5). Results of the meta-analysis of the 45 cases indicate that only 27 percent of the lesson study teams were disseminating results by inviting colleagues and people from outside to the public lesson, distributing the research lesson, presenting in conferences and as articles in journals, while 73 percent of the lesson study teams have "No method for sharing results" (Whitney, 2020, Table I).

Andrée and Eriksson's (2020) project is a part of the "teacher training program" and its teachers and researchers have a special focus to bridge the gap between theory and practice as a platform between university and schools. They addressed, on a general level, teachers' involvement in research as student teachers as well as teachers teaching different school subjects, as necessary condition for building teachers' professional knowledge base. Currently, this project expanded with seven subject-specific networks coordinated by university researchers and $\mathrm{PhD}$ students aiming to bridge the theory-practice gap. The project is a platform between university and schools in order to create a database containing teachers' didactical and professional knowledge. Carlgren $(2012,2020)$ argues that "educational clinical research," such as teachers' research in classrooms, can be comparable to "medical clinical research" accomplished by doctors in clinics. The idea is supported by Wood (2018, p. 170):

Learning study supports the development of clinical practice where the object of learning is explicitly emphasized, combining content, pedagogy and evidence of the lived experiences of individual learners, and where the outcomes are evaluated by the teachers themselves on the basis of evidence and can be reported for the information of others so that they can see what works and why. Being explicit about theory retains the potential to transform teacher education and professional development.

In a similar way, doctors' database for "evidence-based knowledge," teachers with educational researchers could jointly build a database of "teachers' professional knowledge" (Carlgren, 2012, 2020) and the suggestion is a feasible endeavor and not only an idea. Teacher training programs are developed which include training of teachers as researchers, as a mandatory content, and create possibilities to accomplish the idea (Andrée and Eriksson, 2020).

\section{Conclusion}

The aim of this special issue on PER is to investigate the theory and practice gap and its consequences for teachers' participation in research into their own practice and if their participation is dependent on an artifact of the underlying epistemology made visible in the institutional practices of education and teacher training.

Teachers' collaboration in professional communities, as in lesson study, learning study and action research, shares several pedagogical design principles for improving teaching and for improving students' learning outcomes as well as teachers' professional knowledge. Features that are shared are the planning of the lesson; the iterative process of improving a lesson; through planning of a lesson; the accomplishment of the lesson; the reflection of results; and the redesigning of the lesson and enactment of the research lesson. As further guiding principles, Elliott (2020) introduces quality criteria on educational research for improved intentional practice and for course on practiced-based research in schools. Carlgren (2020) goes further and analyzes some learning study from a pragmatic philosophical perspective and finds learning study comparable with a knowledge machinery producing new knowledge applicable beyond the local setting. Kullberg et al. (2020) verify through presentation of three learning studies, its approach to research as a research aiming at improving students' learning, teachers' teaching and teachers' professional knowledge. Findings from the three 
studies are applicable beyond the studies' local settings. In other words, teachers' knowledge becomes visible, useable and disseminated to other teachers (Kullberg et al., 2020). To further bridge the theory and practice gap, Andrée and Eriksson (2020) illustrate a way by building a space (platform) between the university and the school for students in teachers training programs and for teachers in schools. Ousseini (2020) and Biza and Nardi (2020) involve preservice EFL student teachers and mathematical student teachers as participants in their studies in order to increase their awareness of the importance of reflecting on teaching experiences and in introducing steps of the research process. Whitney (2020) accomplished a meta-study of 45 lesson study cases in the USA, out of which 27 percent did some form of dissemination of lesson study results, while 73 percent had no method for dissemination.

\subsection{Implications}

Developmental educational research as improved intentional practice, the theory and practice gap and knowledge shared beyond the local context, themes in the special issue need to be further developed. Theoretical implications concern the involvement of teachers through the entire research process, which ends by a publication. Studies exemplify research, where teachers' training programs involve teachers as researchers in creating and collecting data as well as analyzing data. Other studies conduct almost the entire research process jointly with classroom teachers, except in the writing of articles in most cases. As has been demonstrated, teachers have no possibilities to take part in the entire research process in included studies. The expression "research on teachers" is taken to mean without teacher involvement in the entire research process, i.e., teachers are objects. The expressions "research with teachers" and "research on teachers" seem to be ambiguous as studies have indicated. It seems rather to be question about degrees of involvement in different parts of the research process. Accordingly, research that includes student teachers, teachers and researchers seems partly to be "research with teachers" and partly "research on teachers," due to remaining and underlying epistemological factors in the institutional and system practices, preventing development of education and teacher training.

Practical implications are global obstacles in the sense that teachers' lack of time, and lack of resources are preventing them to become "practicing researchers." Unfortunately, lack of resources prevents school management to support teachers to become "teachers as researchers."

\subsection{Future research}

In future, more research is needed on practice-based educational research. Support needs to come from national level in order to improve students' learning outcomes, teachers' possibilities to become researchers on their own practice and to create a database of teachers' professional knowledge. IJLLS welcomes the submission of teachers' cases of practiced-based research authored by teachers to be shared with the global teaching community.

Airi Rovio-Johansson

Gothenburg Research Institute (GRI), Göteborgs Universitet, Gothenburg, Sweden

\section{References}

Andrée, M. and Eriksson, I. (2020), "A research environment for teacher-driven research - some demands and possibilities", International Journal for Lesson and Learning Studies, Vol. 9 No. 1, pp. 45-55.

Berger, P. and Luckmann, T. (1966), The Social Construction of Reality, Penguin, Harmondsworth.

Biesta, G.J.J. (1994), "Education as practical intersubjectivity: towards a critical-pragmatic understanding of education”, Educational Theory, Vol. 44 No. 3, pp. 299-317. 
IJLLS

9,1

Biesta, G.J.J. (2007), “Why 'what works' won’t work: evidence-based practice and the democratic deficit of educational research", Educational Theory, Vol. 57 No. 1, pp. 1-22.

Biza, I. and Nardi, E. (2020), "Scripting the experience of mathematics teaching: the value of student teacher participation in identifying and reflecting on critical classroom incidents", International Journal for Lesson and Learning Studies, Vol. 9 No. 1, pp. 78-91.

Brydon-Miller, M. and Maguire, P. (2009), "Participatory action research: contributions to the development of practitioner inquiry in education”, Educational Action Research, Vol. 17 No. 1, pp. 79-93.

Carlgren, I.M. (2020), "The knowledge machinery and claims in learning study as paedeutical research", International Journal for Lesson and Learning Studies, Vol. 9 No. 1, pp. 18-30.

Carlgren, I. (2012), "The learning study as an approach for 'clinical' subject matter didactic research", International Journal for Lesson and Learning Studies, Vol. 1 No. 2, pp. 126-139.

Chisholm, R.F. and Elden, M. (1993), "Features of emerging action research", Human Relations, Vol. 46 No. 2, pp. 275-298.

Cochran-Smith, M. and Lytle, S. (1990), "Research on teaching and teacher research: the issues that divide", Educational Researcher, Vol. 19 No. 2, pp. 2-10.

De Vries, B. (1990), The Development of Science, Wolters-Noordhoff, Groningen.

Dewey, J. (1910/1974), "Science as subject matter and as a method”, in Archambault, R.D. (Ed.), John Dewey on Education: Selected writings, University of Chicago Press, Chicago, IL, pp. 182-192.

Dewey, J. (1957), Reconstruction in Philosophy, Beacon Press, Boston.

Dewey, J. and Bentley, A. (1945), "A terminology for knowings and knowns", The Journal of Philosophy, Vol. 42 No. 9, pp. 225-247.

Elliott, J. (1976), "Developing hypotheses about classrooms from teachers' practical constructs", Interchange, Vol. 7 No. 2, pp. 2-22.

Elliott, J. (1978), "What is action-research in schools", Journal of Curriculum Studies, Vol. 10 No. 4, pp. 355-357.

Elliott, J. (2007), "Assessing the quality of research", Research Papers in Education, Vol. 22 No. 2, pp. 229-246.

Elliott, J. (2012), "Developing a science of teaching through lesson study", International Journal for Lesson and Learning Studies, Vol. 1 No. 2, pp. 108-125.

Elliott, J. (2015), "Educational action research as a quest for virtue in teaching", Educational Action Research, Vol. 23 No. 1, pp. 4-21.

Elliott, J. (2020), "Quality criteria for lesson and learning studies as forms of action research", International Journal for Lesson and Learning Studies, Vol. 9 No. 1, pp. 11-17.

Engeström, Y. (1987), Learning by Expanding: An Activity-Theoretical Approach to Developmental Research, Orienta-Konsultit OY, Helsinki.

Engeström, Y. (2016), Studies in Expansive Learning: Learning What is Not Yet There, Cambridge University Press, Cambridge, MA.

Flanagan, J.C. (1954), “The critical incident technique”, Psychological Bulletin, Vol. 51 No. 4, pp. 327-358.

Greenwood, D.J., Foote Whyte, W. and Harkavy, I. (1993), "Participatory action research as a process and a goal", Human Relations, Vol. 46 No. 2, pp. 175-192.

Hanfstingl, B., Rauch, F. and Zehetmeier, S. (2019), "Lesson study, learning study and action research: are there more differences than a discussion about terms and schools?", Educational Action Research, Vol. 27 No. 4, pp. 455-459.

Kemmis, S. (2009), "Action research as a practice-based practice”, Educational Action Research, Vol. 17 No. 3, pp. 463-474.

Knorr Cetina, K. (2001), "Objectual practice”, in Schatzki, T.R., Knorr Cetina, K. and von Savigny, E. (Eds), The Practice Turn in Contemporary Theory, Routledge, London and New York, NY, pp. 175-188. 
Knorr Cetina, K. (1999), Epistemic Cultures: How the Sciences Make Knowledge, Harvard University Press, Cambridge, MA.

Korthagen, F.A.J. (2007), "The gap between research and practice revisited", Educational Research and Evaluation, Vol. 13 No. 3, pp. 303-310.

Kullberg, A. (2010), "What is taught and what is learned: professional insights gained and shared by teachers of mathematics", No. 293, Gothenburg Studies in Educational Science, Acta Universitatis Gothoburgensis, University of Gothenburg, Gothenburg.

Kullberg, A. and Runesson, U. (2013), "Learning about the numerator and denominator in teacher designed lessons", Mathematics Education Research Journal, Vol. 25 No. 4, pp. 547-567.

Kullberg, A., Vikström, A. and Runesson, U. (2020), "Mechanisms enabling knowledge production in learning study", International Journal for Lesson and Learning Studies, Vol. 9 No. 1, pp. 31-44.

Lewis, C. (2009), "What is the nature of knowledge development in lesson study?", Educational Action Research, Vol. 17 No. 1, pp. 95-110.

Lo, M.L. (2012), "Variation theory and the improvement of teaching and learning”, No. 323, Gothenburg Studies in Educational Science, Acta Universitatis Gothoburgensis, University of Gothenburg.

Mårtensson, P. (2019), "Learning to see distinctions through learning studies: critical aspects as an example of pedagogical content knowledge", International Journal for Lesson and Learning Studies, Vol. 98 No. 3, pp. 196-211.

Marton, F. (2015), Necessary Conditions of Learning, Routledge, London and New York, NY.

Nuthall, G. (2004), "Relating classroom teaching to students learning: a critical analysis of why research has failed to bridge the theory-practice gap”, Harvard Educational Review, Vol. 74 No. 3, pp. 273-306.

Ousseini, H. (2020), "Preservice EFL teachers' collaborative understanding of lesson study", International Journal for Lesson and Learning Studies, Vol. 9 No. 1, pp. 56-67.

Oxenberg Rorty, A. (1980), Essays on Aristotle's Ethics, University of California Press, Berkeley, CA.

Pang, M.F. and Runesson, U. (2019), "Guest editorial”, International Journal for Lesson and Learning Studies, Vol. 8 No. 3, pp. 170-182.

Pang, M.F. and Ki, W.W. (2016), "Revisiting the idea of "critical aspects", Scandinavian Journal of Educational Research, Vol. 60 No. 3, pp. 323-336.

Pang, M.F. and Lo, M.L. (2012), "Learning study: helping teachers to use theory, develop professionally, and produce new knowledge to be shared", Instructional Science, Vol. 40 No. 3, pp. 589-606.

Pieters, J.M. and De Vries, B. (2007), "Preface to special issue”, Educational Research and Evaluation, Vol. 13 No. 3, pp. 199-202.

Pieters, J.M. and Voogt, J.M. (2016), "Teachers learning through teachers teams: what makes learning through teams successful?", Educational Research and Evaluation, Vol. 22 Nos 3-4, pp. 115-120.

Posch, P. (2019), "Action research - conceptual distinctions and confronting the theory-practice divide in lesson and learning studies", Educational Action Research, Vol. 27 No. 4, pp. 496-510.

Runesson, U. (2019), "Teachers and researchers in collaboration: a possibility to overcome the research-practice gap?”, European Journal of Education, Vol. 54 No. 2, pp. 250-260.

Runesson, U., Lövström, A. and Hellquist, B. (2018), "Beyond the borders of the local: how 'instructional products' from learning study can be shared and enhance student learning", International Journal for Lesson and Learning Studies, Vol. 7 No. 2, pp. 111-123.

Schatzki, T.R., Knorr Cetina, K. and von Savigny, E. (Eds) (2001), The Practice Turn in Contemporary Theory, Routledge, London and New York, NY.

Slavin, R.E. (2002), "Evidence-based educational policies: transforming educational practice and research", Educational Research, Vol. 31 No. 7, pp. 15-21.

Stenhouse, L. (1975), An Introduction to Curriculum Research and Development, Heinemann Educational, London.
Participatory

Educational

Research 
IJLLS

9,1

10

Stenhouse, L. (1981), “What counts as research?”, British Journal of Educational Research, Vol. 29 No. 2, pp. 103-114.

Takahashi, A. and McDougal, T. (2016), "Collaborative lesson research: maximizing the impact of lesson study”, ZDM Mathematics Education, Vol. 48 No. 4, pp. 513-526.

Van den Akker, J. (1999), "Principles and methods of development research”, in van den Akker, J. (Ed.), Tools in Education and Training, Kluwer Academic, Boston, NY, pp. 1-14.

Whitney, S.R. (2020), “Are lesson study participants sharing their professional knowledge?", International Journal for Lesson and Learning Studies, Vol. 9 No. 1, pp. 68-77.

Wood, K. (2018), "On the theorization of lesson study and learning study", International Journal for Lesson and Learning Studies, Vol. 7 No. 3, pp. 166-171. 